\title{
Art and Nature in Ancient Mechanics
}

\section{Citation}

Schiefsky, Mark J. 2007. Art and nature in ancient mechanics. In The Artificial and the Natural: An Evolving Polarity, ed. B. Bensaude-Vincent and W. R. Newman, 67-108. Cambridge: Massachusetts Institute of Technology Press.

\section{Published Version}

http://mitpress. mit.edu/catalog/item/default.asp?ttype=2\&tid=11371\& mode=toc

\section{Permanent link}

http://nrs.harvard.edu/urn-3:HUL.InstRepos:3708548

\section{Terms of Use}

This article was downloaded from Harvard University's DASH repository, and is made available under the terms and conditions applicable to Other Posted Material, as set forth at http:// nrs.harvard.edu/urn-3:HUL.InstRepos:dash.current.terms-of-use\#LAA

\section{Share Your Story}

The Harvard community has made this article openly available.

Please share how this access benefits you. Submit a story.

Accessibility 
Forthcoming in The artificial and the natural: an evolving polarity, ed. B. Bensaude-Vincent and W. Newman (MIT Press, in press).

\title{
Art and Nature in Ancient Mechanics
}

\author{
Mark J. Schiefsky
}

\section{Introduction}

In this paper I discuss the art-nature relationship in Greco-Roman antiquity with special reference to one important ancient art or technê: mechanics. Although different ancient authors express different views about the goals, methods, and scope of mechanics, they tend to agree in conceiving it as a technê, an art or science, involving a combination of various kinds of theoretical and practical knowledge. In a range of sources from the third century $\mathrm{BC}$ to the third century $\mathrm{AD}$, mechanics is typically described as a techne that includes a wide range of fields, from the theory and practice of building machines for lifting heavy objects to the construction of artillery engines and automata. ${ }^{1}$

This paper addresses two primary questions. First, how did ancient writers on mechanics conceive of the relationship of their technê to nature or phusis? Second, what did these views on the art-nature relationship imply about the ability of mechanics to provide knowledge of nature? According to one line of modern interpretation, advocated by F. Krafft in a series of influential publications, mechanics in antiquity was universally viewed as bringing about effects that were 'contrary to nature' (para phusin); as a result, it is claimed, the study of mechanics could yield no knowledge of nature. Krafft often describes the goal of ancient mechanics as the 'tricking of nature' ('Überlistung der Natur'), and claims that it was only in the early modern period - in the work of Galileo in particular - that the view arose that mechanics follows nature and its laws rather than working against it. ${ }^{2}$ What exactly Krafft means by the tricking of nature is not immediately clear, but the opposition he sets up between tricking nature and following natural laws, as well as his emphasis on the association between mechanics and wonderworking or trickery that can be found in a number of ancient authors, suggest that he understands the tricking of nature to amount to the production of a break or suspension in the order of nature, where this is understood as the domain of a regular, predictable

\footnotetext{
${ }^{1}$ For representative discussions of the various branches of ancient mechanics see the opening chapters of Pappus, Collectio 8 (pp. 1022 ff. Hultsch) and Proclus, In Prim. Eucl. Elem., pp. 41.3 ff. Friedlein. Similar divisions go back to the early Hellenistic period, as shown by the topics covered in Philo of Byzantium's lost Mechanical Syntaxis: the theory of levers, harbor construction, siegecraft, the construction of artillery, pneumatics, and the construction of automata. See Gille 1980, 104-5.

${ }^{2}$ Krafft 1967, 27: 'Die 'Mechanik' galt...in der Antike und im Mittelalter als eine Kunst und hatte als Kunst dort einzugreifen, wo die Natur das vom Menschen Erwünschte nicht von sich aus vollbringen konnte. Das Künstliche ist damit etwas Nicht-Natürliches, ja etwas Naturwidriges. Im Falle der 'Mechanik', der sich Mittel und Werkzeuge zur 'Überlistung' der Natur bedienenden Kunst der Antike, ist diese Auffassung dann endgültig erst von Galileo Galilei und seinen Nachfolgern überwunden worden, die aufzeigten, warum man auch mit mechanischen Hilfsmitteln nur etwas erreichen kann, wenn man der Natur folgt, sich nach ihren 'Gesetzen' richtet. Auch bei der Anwendung einer Maschine geschehe nichts Widernatürliches."
} 
sequence of cause and effect. On this view the effects brought about by mechanics would be 'beyond nature' (para phusin) in the sense of being supernatural, and mechanics itself would amount to a kind of magic. ${ }^{3}$ In other contexts Krafft's view seems to be the more restrained one that mechanics acts 'contrary to nature' in virtue of the fact that it is concerned with forced rather than natural motion in the Aristotelian sense. Since the subject matter of mechanics is limited to forced motion, mechanics is completely distinct from physics, the subject of which is natural motion; once again the conclusion is that the study of mechanics cannot yield any knowledge of nature. ${ }^{4}$ To support this conclusion, Krafft appeals to the general claim that because the Greeks viewed nature as an organic unity, any artificial intervention in natural processes could only distort the behavior of nature rather than helping to reveal it. ${ }^{5}$ The possibility that mechanics might provide knowledge of nature through its use of mathematics is ruled out by Aristotle's view of the relationship of mathematics to physics, which allegedly made it impossible for mathematics to explain any features of the natural world. ${ }^{6}$

I have attempted to set out Krafft's interpretation in some detail because it illustrates a number of assumptions that have strongly colored scholarship on ancient mechanics and indeed on the art-nature relationship in general, assumptions that are deeply problematic if not demonstrably false. To take one example, the notion that the Greek (or, less vaguely, the Aristotelian) concept of nature in itself implied that artificial intervention could yield no knowledge of nature has recently come under well-justified and persuasive criticism. ${ }^{7}$ There is ample evidence from all periods of Greek science for

${ }^{3}$ For the connection between mechanics and magic see Krafft 1973, 7: "Listen und Tricks, Zauberkunst und Magie, versteckte Mittel sind die Werkzeuge der 'Mechaniker'; sie lassen der Natur nicht ihren Lauf, sie überlisten sie und bewirken damit etwas gegen sie..."

${ }^{4}$ Cf. Krafft 1970, 137: “' 'Physik' (phusikê epistêmê) behandelt, wie schon das Wort selbst zeigt, die 'Natur' (phusis) der Dinge, ihr 'Wesen' und ihre 'natürlichen', ihrer 'Natur' gemäßen (Eigen)-Bewegungen, also solche Körper, die, wie Aristoteles es definiert, das Prinzip ihrer naturgemäßen Bewegung in sich selbst haben, während die 'Mechanik', wie wir es besonders aus der Einleitung der Mechanischen Probleme und dem Fehlen einer Behandlung des 'natürlichen' Falles (Freien Falles) ersehen konnten, 'naturwidrige', d. h. künstliche Bewegungen behandelt, Bewegungen, zu denen die 'Natur' eines Körpers nicht selbst in der Lage ist, ja die der 'Natur' eines Körpers entgegen wirken und für deren Zustandekommen sich der Mensch auf kunstvolle Weise 'mechanischer' Hilfsmittel (mêchanai) bedienen muß. Die 'Mechanik' (mêchanikê technê) ist eine 'Kunst', die nach antiker Auffassung deshalb auch zur wissenschaftlichen Erkenntnis der 'Natur', des 'natürlichen' Geschehens nichts Wesentliches beizutragen vermag." For similar remarks see Krafft 1973, 11; 1967, 12-13. Krafft also claims the existence of an 'unüberbrückbare Schranke' between physics and mechanics in antiquity $(1970,138)$.

${ }^{5}$ Krafft 1970, 157: "Da dann seit Platon und Aristoteles die 'Natur' als eine organische Einheit, als ein Ganzes, der Kosmos als ein Lebewesen aufgefaßt wird, kann nämlich die 'Natur' auch eines einzelnen Dinges nicht isoliert betrachtet werden. Greift der Mensch künstlich (mit oder ohne zusätzliches 'Mittel': mêchanê) in den organischen Zusammenhang und den 'natürlichen' Ablauf ein, so kann er nach dieser Auffassung nicht mehr 'Natur' erkennen (Naturwissenschaft treiben), sondern nur noch menschlichen 'Kunst'. Das Experiment trägt als ein solcher 'künstlicher' Eingriff deshalb ebensowenig zur Erkenntnis der 'Natur', zur 'Naturwissenschaft', bei wie eine 'Kunst' und wird als 'naturwissenschaftliches' Erkenntnismittel abgelehnt oder gar nicht erst in Betracht gezogen” Cf. Krafft 1967, 28.

${ }^{6}$ Cf. Krafft 1970, 159: "Die Mathematik gehört nach Aristoteles einem anderen Seinsbereiche als die 'natürlichen' Dinge an. Sie kann deshalb nichts zur Erkenntnis der 'Natur', der Ursachen 'natürlicher' Vorgänge, beitragen und im sublunaren Bereich nicht einmal der Beschreibung dieser Vorgänge dienen.” For similar remarks see Krafft 1967, 30-1.

${ }^{7}$ See especially Newman 1997 and 2001. 
the idea of a close analogy between art and nature, and for the use of analogies between art and nature as a heuristic device for learning about the latter. As far as mechanics itself is concerned, the notion that ancient mechanics was universally viewed as acting 'contrary to nature' (para phusin) is largely based on an interpretation of the earliest extant text devoted to the subject, the Mechanical Problems (Mêchanika Problêmata) commonly ascribed to Aristotle in antiquity and early modern times, but now generally thought not to be by him. ${ }^{8}$ This text opens with a striking passage that describes art in general, and mechanics in particular, as bringing about effects that are para phusin:

Among things that occur according to nature (kata phusin), we wonder at those whose cause is unknown; among things that occur para phusin, we wonder at those that come about by means of art (technê) for the benefit of mankind. For in many cases nature acts in a way opposed to what is useful for us. For nature always acts in the same way and simply, while what is useful changes in many ways. Whenever, then, it is necessary to do something para phusin, because of the difficulty we are at a loss (aporia) and have need of art (technê). For this reason, we also call that part of art that assists in such situations (aporiai) a device (mêchanê). For as the poet Antiphon said, so it is: "By means of art we gain mastery (kratoumen) over things in which we are conquered by nature." Instances of this are those cases in which the lesser master (kratein) the greater, and things possessing a small inclination move great weights, and practically all those problems that we call mechanical. These are not entirely identical with physical problems, nor are they entirely separate from them, but they have a share in both mathematical and physical speculations: for the 'how' in them is made clear through mathematics, while the 'about what' is made clear through physics.'

A central goal of the present paper is to clarify what exactly the author of the Mechanical Problems means in claiming that art produces effects that are para phusin. As already noted, this Greek phrase can be understood in a number of distinct senses. In section 3 below I shall argue that the author's meaning is best captured by the idea that art brings about effects that go 'beyond nature' in the sense that they would not be possible without the intervention of art. These effects, though they go beyond nature and are in that sense unnatural, need not be viewed as acting against nature - whether 'nature' is understood in the global sense as a universal order of cause and effect, or as the specific principle of change present in a particular substance or object. In section 4 I shall argue that despite the apparent conflict between art and nature described at the beginning of the Mechanical Problems, the author's notion of the art-nature relationship is in fact well illustrated by Aristotle's idea that art imitates nature and brings to completion what nature cannot. Moving beyond the Mechanical Problems, the notion that ancient mechanics was universally viewed as operating 'contrary to nature' is further undermined by a consideration of certain branches of mechanics such as the building of automata, which

${ }^{8}$ I will not go into the question of authorship here; what is important for my purposes is simply that the Mechanical Problems clearly lies in the tradition of Aristotelian science.

${ }^{9}$ Mech. 847 a 11 - 28. Translations are my own unless otherwise indicated. For the Greek text of the Mechanical Problems (Mech.) see Apelt 1888. 
were explicitly described as imitating nature. In section $5 \mathrm{I}$ will argue that there are two primary respects in which ancient mechanics could provide knowledge of nature. First, machines could serve as models for understanding processes going on in the natural world. Second, mechanics could yield knowledge of nature through the use of mathematics: mechanics considers certain mathematical properties of physical bodies and uses those properties to explain their behavior.

In order to place these observations on mechanics in a broader context, I shall begin in section 2 with a brief discussion of the art-nature relationship in two important traditions of early Greek thought, Hippocratic medicine and Aristotelian philosophy. Both of these lay great weight on the idea that art imitates nature and can therefore be used as a means of gaining knowledge of it. Finally, in section 6 I discuss a number of attempts from the early modern period to resolve the tensions present in the opening passage of the Mechanical Problems, attempts which show some striking similarities to the interpretation I propose in section 3.

\section{Background}

Before turning to mechanics in particular, it is important to note that the idea of a conflict between art and nature is quite difficult to parallel in antiquity. Ancient authors were much more likely to stress the parallels between art and nature than to portray them as opposed to one another. Two important traditions in early Greek thought provide substantial evidence for this claim: Hippocratic medicine and Aristotelian philosophy. In this section I therefore present brief and necessarily oversimplified accounts of some of the ways in which the art-nature relationship was conceived of in these traditions.

The close connection between art and nature in Hippocratic medicine has two principal aspects. First, a large number of Hippocratic writers conceive of the art or techne of medicine as a systematically organized set of procedures based on a body of theoretical knowledge of human nature (phusis). To be sure, different authors had different conceptions of what this knowledge of human nature amounted to. But many Hippocratics agreed that medicine's claim to be a systematic art or technê depended on its having a basis in some general theory of human phusis. One consequence of the view that medical practice should be based on a theory of human phusis was the idea that the aim of treatment is to restore a patient to his natural condition. Therapy could thus be understood as a matter of 'following nature' by assisting the patient's return to his natural or normal state; indeed in some passages nature is viewed as possessing the ability to bring itself back to health, implying that the doctor's task is only to assist it in this process. Second, there is ample evidence in the Hippocratic literature for the procedure of drawing analogies with artistic or technological processes as a means of learning about human phusis. Again and again the Hippocratics appeal to analogies drawn from the realm of technê to elucidate obscure phenomena such as the growth of the embryo or the behavior of the humors in the body. ${ }^{10}$ In one remarkable passage, the author of the

\footnotetext{
${ }^{10}$ See especially the treatises On Generation, On the Nature of the Child, and On Diseases IV, with the commentary of Lonie 1981.
} 
treatise On Regimen explicitly recommends drawing analogies with technê as a method of studying the obscure realm of human phusis:

But human beings do not understand how to observe the invisible through the visible. For though they make use of arts (technai) that are similar to human nature (phusis), they are unaware of it. The mind of the gods taught them to imitate (mimeisthai) their own [activities], and though they know what they are doing they are ignorant of what they are imitating... But I will show that the well-known arts are like the affections of man, both visible and invisible. ${ }^{11}$

The author goes on to suggest analogies between a wide variety of technological procedures and invisible processes taking place inside the human body. Though some of these analogies are highly obscure, it is clear that many of them appeal to the idea that artistic processes are either closely similar or identical to those that occur in the human body; it is because of this that an understanding of technê can be used to gain knowledge of human phusis. ${ }^{12}$

Turning to Aristotle, it is well known that he distinguishes between natural things and artefacts on the ground that the former possess an internal principle of change while the latter do not (Phys. 192 b 8 - 32). But it would be a serious mistake to conclude from this that Aristotle viewed artefacts as inherently inferior to the products of nature, or held that artificial interference with the behavior of a natural object can reveal nothing about its nature. ${ }^{13}$ Aristotle often emphasizes the similarity of natural and artificial processes. In Physics B 8 he famously appeals to the analogy between art and nature to support the claim that nature is inherently teleological or end-directed:

Further, where there is an end, all the preceding steps are for the sake of that. Now surely as in action, so in nature; and as in nature, so it is in each action, if nothing interferes. Now action is for the sake of an end; therefore the nature of things also is so. Thus if a house, e.g. had been a thing made by nature, it would have been made in the same way as it is now by art; and if things made by nature were made also by art, they would come to be in the same way as by nature. The one, then, is for the sake of the other; and generally art in some cases completes (epiteleitai) what nature cannot bring to a finish, and in others imitates her (mimeitai). If, therefore, artificial products are for the sake of an end, so clearly also are natural products. The relation of the later to the earlier items is the same in both. ${ }^{14}$

Two points about this crucial passage deserve special emphasis. First, the context makes clear that Aristotle's notion of imitation goes far beyond mere mimicry. His main purpose is to argue that nature, like art, operates in a goal-directed manner, and his point is that both natural and artificial processes take place in an ordered sequence in which each

\footnotetext{
${ }^{11}$ Hp. Vict. 11-12, 6.486-488 Littré.

${ }^{12}$ On this passage cf. Schneider 1989, 208-212; he rightly insists that the analogies imply the existence of structural similarities between technê and phusis.

${ }^{13}$ See Newman 1997 for another critique of these traditional assumptions.

${ }^{14}$ Arist. Phys. 199 a 8 - 20. Translation Barnes.
} 
stage comes about for the sake of the next. What Aristotle has in mind is thus a close analogy between natural and artificial processes. ${ }^{15}$ Second, the passage gives a precise meaning to the notion that art goes beyond nature. In producing an artefact such as a house or a ship, art brings about results that nature itself cannot. But because of the close analogy between art and nature, this is really just a matter of bringing to completion what nature leaves unfinished. Art, by acting in a natural way - the way nature would act if it could generate the products of art - is able to produce results that do not come about by nature alone. ${ }^{16}$

Aristotle often contrasts art and nature as external and internal principles of change, respectively, as in the following passage from the Nicomachean Ethics:

All art is concerned with coming into being, i.e. with contriving and considering how something may come into being which is capable of either being or not being, and whose origin is in the maker and not in the thing made; for art is concerned neither with things that are, or come into being, by necessity, nor with things that do so in accordance with nature (kata phusin) (since these have their origin in themselves). ${ }^{17}$

To the extent that the art-nature distinction is simply a distinction between external and internal sources of change, it allows for a close parallel between natural and artificial processes. This parallel is emphasized in Aristotle's extended account of artificial and natural generation in Metaphysics Z 7-9. In both cases a form is realized in matter; in artificial generation the form is originally present in the soul of the artisan, while in natural generation it originates in the parent. In a sense, then, the form is imposed from outside in natural generation as well. A passage of the De Generatione Animalium makes a similar point:

Art is the principle and form of the thing that comes to be; but it is located elsewhere than in that thing, whereas the movement of nature is located in

\footnotetext{
${ }^{15}$ Cf. Phys. 199 b 28 - 9: if the art of shipbuilding were present in the wood, a ship would come to be by nature in the same way that it does by art.

${ }^{16}$ For a similar interpretation of Aristotle's remark that art imitates nature or brings to completion what it cannot see Schadewaldt 1970a, 900-901:"Dieser Satz meint natürlich nicht, daß die Technik lediglich die Natur nachäffe (obgleich die Technik, wenn ich recht unterrichtet bin, in vielen Zweigen auch heute wirklich zunächst einmal die Natur befragt). Er meint, wenn man ihn richtig faßt: daß die Technik in Analogie zur Natur handelt, daß sie in ihrem eigenen Tun die zunächst einmal grundwissenschaftlich erforschten Prinzipien der Natur befolgt. In immer neuen Kombinationen und Gestaltungen auf Grund der zunächst einmal erforschten Prinzipien der Natur gelangt die Technik auf ihre partielle Weise zu neuen Kombinationen, die auf den Menschen abgestellt sind. In diesem Sinne sagt auch Aristoteles, da $\beta$ 'die Technik weiter und zu Ende führe, was die Natur von sich aus bisher noch nicht bewerkstelligt' hat. Dieses Weiter- und Zu-Ende-Führen ist das, worin die Technik in ihrer Weise sich mit Recht der Natur 'überlegen' fühlen darf. Im ganzen aber beruht eben diese ihre 'technische' Überlegenheit darin, daß sich die Technik zunächst einmal der Natur einschmiegt, ihr gehorcht und auf sie hinhört, so wie das treffend Bacon gesagt hat: natura parendo vincitur (original emphasis)." Cf. also Schneider 1989, 214-5.

${ }^{17}$ Arist. EN 6, 1140 a 10 - 16. Translation Barnes.
} 
the thing itself that comes to be, and is derived from another natural organism which possessed the form in actuality. ${ }^{18}$

Although Aristotle contrasts art and nature here, this remark in fact comes at the conclusion of an extended analogy between them. Just as hot and cold do not suffice of themselves to temper iron in the way necessary to make a sword but must act in accordance with the form specified by art, so in the formation of the embryo the action of hot and cold will only generate the right parts if directed by the form supplied by the parent (734 b $28-735$ a 3). The upshot is to stress the similarity of natural and artificial generation, even if the source of change in the former is internal rather than external.

In some Aristotelian passages the boundary between artificial and natural processes is quite unclear. Important evidence of this is provided by Meteorology IV, a text whose authorship is disputed but which (like the Mechanical Problems) clearly belongs in the tradition of Aristotelian philosophy and science. The book discusses various transformations between natural substances, especially those brought about by hot and cold. Chapters 2 and 3 focus on the process of coction or pepsis (defined at $379 \mathrm{~b}$ 18-19 as "perfection brought about by a thing's own natural heat") and its various species, which are said to be ripening, boiling, and roasting. In the author's usage, pepsis is thus a generic term that subsumes artificial as well as natural processes. The author builds on ordinary usage, in which pepsis refers to a wide variety of natural changes such as the ripening of fruit and digestion as well as artificial processes such as cooking. Two passages in the discussion of pepsis make explicit reference to the art-nature relationship. First, in concluding his discussion of boiling the author remarks that "Such, then, is what is called coction (pepsis) by boiling: and it makes no difference whether it takes place in artificial or natural instruments (organois), for the cause will be the same in all cases." 19 Second, in the discussion of roasting (defined at 381 a $23-4$ as "coction by extrinsic dry heat") he states:

Now roasting and boiling are artificial processes, but, as we have said, the same general kind of thing is found in nature too. The affections produced are similar though they lack a name; for art imitates (mimeitai) nature. For instance, the coction (pepsis) of food in the body is similar to boiling, for it takes place in a hot and moist medium and the agent is the heat of the body. ${ }^{20}$

While the first of these passages suggests that there is no difference between artificial and natural processes, the second seems to indicate that they are closely similar rather than identical: boiling and roasting have natural counterparts for which there is no name but which are similar to them in kind or eidos. But whatever the author's exact conception of the relationship between artificial and natural processes, these passages clearly imply that the study of the former can yield an understanding of the latter, whether by analogy or direct inference. ${ }^{21}$ The view that artificial processes are either closely similar or identical

\footnotetext{
${ }^{18}$ Arist. $G A 735$ a $2-4$.

${ }^{19}$ Meteor. IV, 381 a $9-12$.

${ }^{20}$ Meteor. IV, 381 b 3 - 9.

${ }^{21}$ On the influence of these passages on early modern alchemy, see Newman 2001.
} 
to natural ones underlies Aristotle's extensive appeal to analogies between technê and phusis, which are especially common in the biological works. Because the processes of art are similar or identical to those of nature, art can serve as a model for the understanding of nature. ${ }^{22}$

To be sure, the art-nature relationship was not always described as one of imitation. Near the end of the Hippocratic treatise On the Art, the author states that in the case of diseases that affect the internal organs, medicine makes use of visible symptoms to diagnose the patient's condition. But when nature does not reveal such symptoms of its own accord, the art has discovered means of compelling it to do so:

When this information is not revealed, and nature itself will yield nothing of its own accord, medicine has found means of compulsion (anagkai), whereby nature is constrained (biastheisa), without being harmed, to give up its secrets; when these are given up it makes clear, to those who know about the art, what ought to be done..$^{23}$

By administering certain foods and drinks or prescribing certain exercises, the doctor can force the patient's phusis to give evidence of its condition. The language of this passage, which suggests the image of nature undergoing torture, could hardly be more striking. Yet while it portrays the art-nature relationship as one of antagonism rather than imitation, the passage does not suggest that the secrets nature is compelled to reveal are in any way unnatural. The point is simply, as Heraclitus put it, that "nature loves to hide." ${ }^{24}$ Nature does not reveal its secrets without being subject to compulsion, but that does not make them any less a manifestation of nature. Here, then, we have a clear case where artificial modification and even compulsion must be used in order to gain knowledge about nature; there is no suggestion that such compulsion in any way distorts the information that it provides.

In conclusion, the notion that art imitates nature plays an important role in both Hippocratic medicine and Aristotelian philosophy. This notion in turn rests on the close similarity between natural and artificial processes. As Aristotle put it, art can go beyond nature, but in doing so it acts in the way that nature would act, if it could bring about such results. Both Aristotle and the Hippocratics make extensive use of technical analogies as a means of learning about phusis. There is, then, no a priori reason to suppose that mechanics could yield no knowledge of nature simply because it was viewed as a technê. Indeed the evidence discussed in this section suggests exactly the opposite conclusion.

\footnotetext{
${ }^{22}$ For Aristotle's use of technological analogies cf. Bourgey 1975, Lloyd 1966.

${ }^{23} \mathrm{Hp}$. de Arte 13, 240.10-13 Jouanna, 6.24 Littré.

${ }^{24}$ Fr. 123 Diels-Kranz (DK).
} 


\section{Art and Nature in the Mechanical Problems}

With these considerations in mind we may turn to the interpretation of the artnature relationship in the Mechanical Problems. The author begins by distinguishing between two kinds of phenomena that excite wonder: those that come about 'according to nature' (kata phusin) and whose cause is unknown, and those that come about para phusin by means of art (technê), for the benefit of human beings. Nature often acts in a way that is opposed to what is beneficial for human beings; this is because it always acts in the same way, while human needs vary widely. Nature's constant, unvarying activity leads to difficulties; confronted with these, human beings are often at a loss (aporia) and must make use of art (technê). Hence the part of technê that provides assistance in such situations is called a 'device' (mêchanê). A quotation from the poet Antiphon sums up the author's view of the art-nature relationship: art enables human beings to triumph over matters in which they are conquered by nature.

Before going further it is essential to distinguish a number of senses that might be conveyed by the phrase para phusin in Greek. At least four are relevant. (1) First, para phusin may refer to something that is 'beyond nature' in the quite strong sense of beyond the order of nature, understood as a domain of the orderly sequence of cause and effect: in other words, the supernatural. On such a view mechanics would amount to a kind of magic. (2) Second, para phusin might refer to something that is contrary to a specific nature, understood as an internal principle of change in the Aristotelian sense. As is well known, Aristotle uses the phrase para phusin to refer to motions that are contrary to the natural motion of an element: fire moves upwards kata phusin and downwards para phusin. $^{25}$ In some Aristotelian contexts the distinction between para phusin and kata phusin motion amounts to a distinction between motion caused by external force or compulsion (bia) and that which is caused by an internal principle of change. ${ }^{26}$ It is in any case clear that para phusin in this sense involves no break or rupture in the order of nature; indeed Aristotle himself points to the existence of natural motions that are para phusin, e.g. lightning that moves downwards despite its fiery nature. ${ }^{27}$ (3) Third, para phusin in Aristotle often refers to what is unusual, while kata phusin refers to what occurs usually or for the most part. This usage is particularly common in Aristotle's biological works, where para phusin is often used of monstrous births. ${ }^{28}$ Again, however, it is clear that Aristotle does not understand such phenomena as lying outside the domain of nature. A passage of the De Generatione Animalium makes the point especially clearly:

A monstrosity (teras) belongs to the class of things contrary to nature (para phusin), although it is not contrary to nature in its entirety but only to nature as it holds for the most part. As for the nature which is always and by necessity, nothing occurs contrary to that: unnatural occurrences are found only among those things that happen as they do for the most

\footnotetext{
${ }^{25}$ Cf. Phys. 230 b $10 \mathrm{ff}$.

${ }^{26} \mathrm{Cf}$. Cael. 300 a 23: to de biai kai para phusin tauton.

${ }^{27}$ Meteor. 342 a 12-16. For the general point that para phusin motion does not violate the order of nature see Schneider 1989, 260-1; Micheli 1995, 30.

${ }^{28} \mathrm{Cf}$. GA 772 a 36-37, where monstrous births are said to come about "contrary to what happens for the most part and usually" (para to hôs epi to polu kai to eiôthos).
} 
part, but which may happen otherwise. For even in these cases, something comes about that is contrary to this particular order, but never in a merely random fashion; thus it seems less of a monstrosity (teras), because even that which is contrary to nature (para phusin) is, in a way, in accordance with nature (kata phusin) (i.e. whenever the formal nature does not master the material nature). ${ }^{29}$

Though para phusin in virtue of being unusual, monstrous births are also kata phusin, both in the sense that they come about in nature and in the sense that they can be explained in terms of the behavior of specific natures: for they come about when the formal nature fails to master the material, and are thus in accordance with the nature of the elements. ${ }^{30}$ (4) Finally, para phusin might be taken to refer to what goes 'beyond nature' - not in the strong sense that it lies outside nature understood as the domain of a regular sequence of cause and effect, but in the sense of something that nature cannot or does not do without the intervention of art. In this section I aim to show that it is this last sense that best captures the author's conception of mechanical phenomena and their relationship to nature. Art in general, and mechanics in particular, go beyond what unaided nature can achieve - but they do not lie outside the domain of nature, and they do not even necessarily involve forced motion in the Aristotelian sense of motion contrary to a thing's specific nature.

With these distinctions in mind we may now turn to the interpretation of the Mechanical Problems itself. At the opening of the text art is described as bringing about effects that are para phusin, and art and nature are opposed to one another. But it is immediately evident that this is in fact an opposition between nature and human needs: art acts to benefit human beings, while nature often behaves in ways that are 'opposite' or 'contrary' (hupenantion) to what is useful for mankind. And this in turn is explained in terms of another opposition: nature always acts in the same way and 'simply' (haplôs), while what is useful varies in many ways (pollachôs). Thus the opposition between art and nature comes down to a contrast between the varied complexity of art and the simplicity and constancy of nature. Art is more complex than nature and brings about effects that are beneficial for human beings; in so doing it acts para phusin, but this does not imply that it works against nature. The contrast between the simplicity of nature and the complexity of art rather suggests that art works by making creative use of nature's

\footnotetext{
${ }^{29}$ Arist. GA 770 b 9 - 17.

${ }^{30}$ Cf. Phys. 197 b 32 - 37, where Aristotle states that the difference between chance (tuchê) and spontaneity (to automaton) is especially clear in the case of things that come about by nature: "The difference between spontaneity and what results by chance is greatest in things that come to be by nature (phusei); for when anything comes to be contrary to nature (para phusin), we do not say that it came to be by chance, but by spontaneity. Yet strictly this too is different from the spontaneous proper; for the cause of the latter is external, that of the former internal" (translation Barnes). Here again we have an example of phenomena which, though they come about by nature, are also para phusin. Both chance and spontaneity are concerned with the production of end-like results; the difference between them is that the former is restricted to results that could be brought about by human choice (cf. 197 a $36 \mathrm{ff}$.). Thus what Aristotle is referring to are endlike results that arise in nature but are produced in an unusual or exceptional fashion; Ross is probably correct to argue that the reference is to spontaneous generation, in which normal offspring are produced in a way that deviates from the usual process of generation from seed (Ross 1936, 524).
} 
constant, regular behavior to bring about beneficial effects. To be sure, the behavior of nature leads to difficulty, which can only be overcome by means of art: "Whenever, then, it is necessary to do something para phusin, because of the difficulty we are at a loss (aporia) and have need of art (technê)." But there is no need to understand this difficulty as the result of nature's active resistance to the efforts of art; the point is simply that it is challenging to adapt or direct nature's constant course toward the diversity of human needs. Rather than describing a struggle between art and nature, the opening sentences of the Mechanical Problems in fact suggest the ability of art to go beyond nature by producing more complex effects that are also beneficial for human beings.

The notion that art aims at an end that is beneficial for human beings is deeply rooted in the tradition of Greek thought about techne. The same is true of the idea that technê enables human beings to escape from a situation of need or helplessness (aporia), and that it does so by means of a 'device' or mêchanê. In Greek literature of the fifth and fourth centuries $\mathrm{BC}$ the term mêchanê commonly refers to a means, device, or stratagem, whether physical or intellectual, that enables a person to escape from a situation of difficulty. Conversely, the term amêchania refers to helplessness in such a situation. Two familiar passages from fifth-century tragedy provide good illustrations of this complex of ideas. (1) In the Prometheus Bound attributed to Aeschylus, the character Prometheus describes how human beings originally lived a helpless existence, lacking all the benefits of technology, and how he enabled them to rise above this primitive state by discovering the arts (technai): astronomy, counting, writing, the domestication of animals, seafaring, medicine, prophecy, and mining (447ff.). Yet despite these discoveries he lacks the ability to free himself from imprisonment at the hands of Zeus: "Wretched I am: such are the means (mêchanêmata) I discovered for mankind, yet I have no skill (sophisma) to rid myself of the present calamity" (469-471). Prometheus' mêchanêmata are 'means' that assist human beings in a condition of need. ${ }^{31}$ (2) The first stasimon of Sophocles' Antigone (332ff.) celebrates human intelligence as the faculty that enabled human beings to discover the arts and overcome the dangers of a hostile natural world. Man the 'skillful' (periphradês) has devised means of capturing all manner of animals; by means of 'skillful contrivances' (mêchanai) he is able to overcome (kratein) wild beasts (342ff.). With the aid of the arts (technai) man is 'all-resourceful' (pantoporos) and goes to meet nothing in the future 'without resource' (aporos); medicine even has the ability to deal with 'unmanageable' (amêchanôn) diseases, and its power is limited only by the certainty of death (360-364). It is the inventive ingenuity associated with mêchanê that enables human beings to discover the arts: "Clever (sophon) beyond hope is the contrivance of his art (to mêchanoen technas), and he advances sometimes to evil, at other times to good." ${ }_{32}$ In these and many other passages, mêchanê and related terms convey the ideas of inventiveness, flexibility, and adaptability to different circumstances - qualities that fit very well with the contrast between the uniformity of nature and the diversity of human needs stressed at the opening of the Mechanical Problems. A mêchanê is a means or

\footnotetext{
${ }^{31}$ Cf. also Prom. 476-477: "Hear the rest and you shall wonder all the more at the arts (technai) and resources (poroi) I have devised"; 506: "All the arts (technai) have come to human beings from Prometheus." Prom. 109-110 describes fire, Prometheus' key discovery, as a "great resource (poros)" and "teacher of all the arts."

${ }^{32}$ Soph. Ant. 365-7.
} 
instrument that enables human beings to make creative use of circumstances at their disposal to attain an end that would otherwise be impossible to achieve. ${ }^{33}$

In some contexts mêchanê carries strong connotations of trickery or deception. ${ }^{34}$ Clearly the kind of inventive ingenuity associated with the term was sometimes viewed as suspicious or devious. Yet already in Herodotus and the Hippocratic writers mêchanê is used of a physical device or machine, with no connotations of trickery or deceit; in such contexts, however, it is often implicit that the device in question makes it possible to attain a goal that could not otherwise be achieved. ${ }^{35}$ To conclude from the fact that mêchanê sometimes has connotations of trickery or deception that the author of the Mechanical Problems viewed mechanics as an art of tricking nature would be quite unjustified. There is no reason to import the idea of 'trick' or 'ruse' into the present passage: a mêchanê is simply a device or means that enables human beings to direct the constant, regular course of nature towards their more complex needs. ${ }^{36}$

The author continues with a quotation from the poet Antiphon: by means of art human beings triumph (kratein) over things in which they are conquered (nikômetha) by nature. The language of triumph (kratein) and victory (nikometha) suggests the image of art struggling with and conquering a hostile nature. But Antiphon does not actually state that art conquers nature, and in fact the idea expressed by his remark is rather more

\footnotetext{
${ }^{33}$ For other examples of mêchanê as a 'means' or 'Hilfsmittel' cf. Aesch. Sept. 208f.; Hdt. 2.181; Eur. Phoen. 890, Hel. 1034; Hp.VM 19; Aristoph. Thesm. 765; Plat. Apol. 39a. At Gorg. 512b Plato cites the engineer or mêchanopoios along with the general and the sea captain as people whose function is to rescue individuals from situations of difficulty. For the connection between mêchanê and poros cf. Eur. Med. 260, Hel. 813; Plat. Crat. 409d, 425d. For the adaptability of mêchanê cf. the use of the term with the verb plekein 'to weave' (e.g. Eur. Andr. 66, 995; Or. 1423) and the adjective poikilos 'varied' (e.g. Soph. OC 762).

${ }^{34}$ See LSJ s.v. II, noting that the sense of trickery or deception is characteristic of the plural mêchanai ('shifts, devices, wiles').

${ }^{35}$ See Hdt. 2.125 for mêchanê as a crane or other lifting device used in the building of the pyramids; Hp. Fract. 30, Art. 72 for mêchanê as a device (e.g. a lever) used to treat fractures and dislocations. Hp. Fract. 30 states that mechanical methods should only be used when human strength is insufficient to deal with a fracture. For mêchanê of a construction cf. Aeschylus' reference to Xerxes' bridge across the Hellespont as laoporoi mêchanai (Pers. 105-6; Pers. 722 remarks that Xerxes bridged the Hellespont by means of mêchanai). In Thucydides mêchanê is regularly used of a siege engine $(2.76,3.51,4.13,8.100)$. On these passages cf. Schneider 1989, 220: "Der terminus technicus wahrt den älteren Wortsinn insofern, als es sich um Instrumente handelt, ohne die der Mensch einen bestimmten Zweck nicht erreichen kann." Elsewhere mêchanê refers to a theatrical device used to make gods appear in the air; cf. Plat. Crat. 425d, where it is remarked that tragic poets resort to a mêchanê of this type when they are at a loss (aporôsin) about how to resolve the plot of the drama. The verb mêchanaomai, though it sometimes means to plot or intrigue, is often used quite neutrally to mean prepare or contrive in a skilful manner (e.g. Hdt. 1.123, where it is paired with the verb epitechnasthai, 'to devise with skill') or by the use of mechanical devices (e.g. Hp. Fract. 30, 31; Art. 74).

${ }^{36}$ On the meaning of mêchanê and related terms see especially Schadewaldt 1970b, 914, accepting the derivation of mêchanê from the Doric word mêchos ('means, expedient, remedy', not 'trick') and taking the basic sense of the term to be "'Abhilfe', 'kluger Ausweg', 'klug ergriffenes Mittel', mit dem man irgendeiner Sache beikommt." Krafft's remarks (1967, 15 f.; 1970, 140 f.; 1973, 5 - the latter two discussions add nothing substantial to the first) are now superseded by those of Schneider $(1989,217-222)$ and, most recently, Micheli (1995, 9-20). Micheli also quite rightly emphasizes that mêchanê at the opening of the Mechanical Problems has no connotations of deception or trickery $(1995,28)$.
} 
precise: technê enables human beings to overcome natural disadvantages and thus to attain control and mastery over the natural world. The background to Antiphon's remark is a view of the origins of culture that was widely shared in the fifth century BC, according to which human beings are described as struggling to overcome the dangers of a hostile environment. In one scenario that can be traced back to fifth-century sources, human beings are said to be inferior to animals in physical characteristics such as speed and agility, but to make up for this by their intellect and the development of technology. ${ }^{37}$ A similar picture is suggested by the first stasimon of Sophocles' Antigone: through his amazing intelligence, man has developed the ability to overcome the dangers of the natural world; he 'masters' (kratein) wild beasts by means of 'devices' (mêchanai). The idea that art enables human beings to overcome natural limitations and to achieve control and mastery over the natural world does not in itself imply anything about how it does so. In particular, it does not imply that art causes a break or rupture in the natural order of cause and effect (para phusin in sense 1 as defined above), or even that it acts against the natural tendencies of particular objects or substances (para phusin in sense 2). Art 'conquers' nature by enabling human beings to modify nature's behavior in beneficial ways, and thus to overcome their natural limitations. Once again the idea is that art goes beyond nature by producing beneficial effects that nature would not if left to itself. It is notable that in contrast to some fifth-century sources, the author of the Mechanical Problems does not portray nature as a hostile force that threatens the very existence of humanity. For him the opposition between nature and human needs arises solely from the contrast between the constancy and uniformity of the former and the complexity and diversity of the latter..$^{38}$

Up to this point the author's remarks have been concerned with art in general rather than mechanics in particular. Next, at 847 a $22 \mathrm{ff}$., he attempts to define the character of mechanics more precisely. Mechanical problems are those in which "the lesser master (kratei) the greater, and things possessing a small inclination (ropê) move great weights." This builds on the idea of overcoming natural disadvantages expressed in the Antiphon quote. Though the strength of human beings is limited by nature, these limits can be exceeded by means of mechanics, which makes it possible to move great weights with only a small force. Additionally, this way of describing mechanical effects implies that they are para phusin in the third sense distinguished above, the unusual or paradoxical. It is normal or natural for a greater force to 'master' a lesser, and for large weights to be moved by large forces; mechanics brings about a reversal of this situation. What distinguishes mechanical effects is not so much that they involve forced motion in the Aristotelian sense (para phusin in sense 2); the emphasis, rather, is on the fact that they bring about a reversal of the normal relationship between forces. ${ }^{39}$

\footnotetext{
${ }^{37} \mathrm{Cf}$. Anaxagoras fr. $21 \mathrm{~b}$ DK and the story of Prometheus and Epimetheus as told in Plato's Protagoras (320 c ff.).

${ }^{38}$ Cf. Schneider 1989, 236; 256 n. 177 (rightly insisting, against Vernant 1957, that the Mechanical Problems does not describe a "combat de la technê contre le phusis.")

${ }^{39} \mathrm{Cf}$. Piccolomini 1565, 7-8: Haec itaque, cum ui quadam contingant, praeter naturam dicuntur fieri, atque horum causam, hoc est ipsam uiolentiam, cum uel ignoramus, uel minorem arbitramur quam effectus appareant, miramur ocius (my emphasis).
} 
After a brief remark on the relationship between mechanics, mathematics, and physics (to which I will return below) the author turns to the discussion of circular motion, which he claims to be the fundamental explanation of practically all mechanical phenomena. The remainder of the introductory section (847 a 28 - 848 a 37) establishes an association between wonder and the strange or atopon, and an opposition between both these ideas and the notions of nature (phusis) and cause (aitia). The author begins by mentioning the lever as a paradigm example of a mechanical device: it enables a large weight to be moved by a small force, even though its own weight must be moved in addition. Again, what is emphasized is not that the lever causes a weight to move in a way that is contrary to its natural inclination (para phusin in sense 2); the point is rather that it reverses the normal (i.e. natural) relationship between forces (para phusin in sense 3 ). Hence the operation of the lever appears strange or atopon (847 a $28-b$ 15). But in fact it can be explained by reference to the circle:

Now the primary cause (tês aitias tên archên) of all such phenomena is the circle; and this is reasonable, for it is in no way strange (atopon) that something wondrous (thaumaston) should result from something more wondrous (thaumasioteron), and the most wondrous thing (thaumasiôtaton) is the combination of opposites with one another. The circle is made up of such opposites, for to begin with it is composed of both the moving and the stationary, whose natures (phusis) are opposed to one another. So that when one reflects on this, there is less reason to wonder (thaumazein) at the oppositions that occur in connection with it. ${ }^{40}$

The lever is both 'strange' (atopon) and 'wondrous' (thaumaston). In part, its wondrous character is explained by something even more wondrous: the circle, in which opposites are combined with one another. Yet the circle itself is said to be much less wondrous once its nature as a combination of opposites is understood. Since the circle is the ultimate explanation of all mechanical phenomena, the upshot is that a machine like the lever is no longer strange or wondrous once its operation has been explained in terms of circular motion. The wondrous properties of the circle include (1) the presence of both concave and convex in the circumference (847 b 23 - 848 a 3) and (2) the fact that it moves simultaneously in opposite directions, both forward and backward (848 a 3 - 10; the idea seems to be that a point on a circle moves in the opposite direction from the point diametrically opposed to it when the circle rotates; cf. 848 a 19 ff.). But the most important reason why the circle is a source of wonders in fact has nothing to do with this mysterious union of opposites: as it rotates, a point farther from the center moves more quickly than one closer to the center (848 a 14 - 19). At 848 a 11 - 14 the author expands on his earlier remark that the circle is the primary cause of all mechanical phenomena:

The things that occur with the balance can be referred to the circle, and those that occur with the lever to the balance; while practically everything else concerned with mechanical motions can be referred to the lever.

\footnotetext{
${ }^{40}$ Mech. 847 b $15-23$.
} 
This suggests a highly systematic procedure of explaining all mechanical phenomena in terms of circular motion. Since the operation of the lever is explained by reference to the balance, and that of the balance by reference to the circle, it is only necessary to show how a particular mechanical phenomenon can be analyzed as the operation of a lever in order to explain it in terms of the circle. In this sense the circle is the fundamental explanation of all mechanical phenomena, making their character as 'wonders' only apparent.

The final part of the introductory section (848 a 19 - 37) describes a mechanical device whose operation depends on the fact that the circle combines opposite movements. The exact nature and function of this machine are unclear. However, it is apparent that it involves a number of circles placed along a line and in contact with one another, so that when the first one rotates it causes the second to turn in the opposite direction, and so forth. The section concludes with the following important remark:

Craftsmen, seizing on this natural property (phusis) of the circle, construct an instrument by concealing the principle (archê), so that only the wondrous character (to thaumaston) of the machine (mêchanêma) is apparent, while its cause (aition) is unclear. ${ }^{41}$

Here again the the ideas of nature, principle, and cause are associated with one another and opposed to wonder. The operation of this machine is wondrous only if the causal principle (archê) that explains it is concealed. Moreover the machine is constructed not by working against the nature (phusis) of the circle but by making creative use of it. If there is trickery in mechanics, it is not trickery of nature but trickery of the ignorant observer who is unaware of the true explanation of mechanical phenomena. ${ }^{42}$

\footnotetext{
${ }^{41}$ Mech. 848 a $34-37$.

${ }^{42}$ See Micheli 1995, 34. For an example of similar trickery of the ignorant observer cf. 849 b $34-850$ a 2: sellers of purple attempt to distort the readings of balances by changing the suspension point or the weight of one of the arms. For a further example of the association of the strange or atopon and wonder (to thaumaston) cf. 855 a $28 \mathrm{ff}$. (a description of the paradoxes involved in the 'wheel of Aristotle'), where the author goes on to give the cause (aitia) at $855 \mathrm{~b} 32 \mathrm{ff}$. I do not mean to deny that trickery and the production of wonder were important goals in certain branches of ancient mechanics. Thus Pappus states that the practitioners of a number of branches of ancient mechanics were known as 'wonder-workers' (1024.24-28 Hultsch): "The ancients also call the wonder-workers (thaumasiourgoi) mechanicians. Some practice their art (philotechnousin) by means of air, as does Hero in his Pneumatics; others seem to imitate the motions of living things through ropes and cables, as does Hero in his Automata and Balances; still others make use of bodies carried on water, as Archimedes does in his Floating Bodies, or water-clocks, as Hero does in his Water-Clocks, which is evidently connected with the theory of the sundial (gnomonikê)." In Proclus' account (In Prim. Eucl. Elem., $41.3 \mathrm{ff}$. Friedlein) the production of wonders (thaumatopoiikê) is a major component of the science of mechanics; this includes the manufacture of (a) devices based on air, as described by Hero and Ctesibius (i.e. pneumatics), (b) devices based on inclinations (ropai), with equilibrium producing rest and lack of equilibrium motion, (c) devices that imitate (apomimeisthai) living things through ropes and cables (i.e. the building of automata). As both Pappus and Proclus indicate, the production of wonders was particularly associated with the building of automata and pneumatic devices. It is clear from Hero's remarks in the introductions to his works on automata and pneumatics that the production of stunning or remarkable effects was an explicit goal of these branches of the mechanical technê; cf. Aut. 1, Pneum. 1, and, for a later example, the passage from Cassiodorus discussed in section 4 below. What I wish to emphasize is simply that there was nothing mysterious or inexplicable about the
} 
Thus, while the author of the Mechanical Problems emphasizes the wondrous character of mechanical phenomena, it should be clear that this is not because he thinks that they fall outside the domain of nature understood as the realm of the regular progression of cause and effect (i.e. para phusin in sense 1). Such phenomena are wondrous because they are unusual or paradoxical (para phusin in sense 3), and their wondrous character disappears once they have been explained. The author's attitude toward wonders is similar to that of other early Greek thinkers committed to the view that all phenomena can be explained in terms of natural causes. Within this framework, wonders constituted a class of unusual, problematic phenomena that could in principle be explained, and which provided a stimulus to scientific inquiry. ${ }^{43}$ The idea is of course Aristotelian. In the Metaphysics Aristotle identifies the wonder felt in response to phenomena such as eclipses as the starting point of philosophy and science; he goes on to mention automata as a paradigm example of a device that is wondrous only to those who do not understand the cause (aitia) that explains its operation. Once this cause is grasped, such devices are no more wondrous than the incommensurability of the diagonal to a person trained in geometry; indeed nothing is more wondrous to a geometer than the notion that the diagonal is commensurable with the side. ${ }^{44}$ The notion that the wonder of mechanical phenomena disappears once they have been explained tends to break down the barrier between the artificial and the natural set up in the opening sentence of the Mechanical Problems. For it turns out that the effects produced by art, just like natural phenomena, are wondrous only insofar as their causes are unknown. ${ }^{45}$

After this introduction, the author discusses 35 'problems' or puzzling mechanical phenomena. Many of these are drawn from the experience of everyday life or technological procedures; others are more theoretical in nature. By far the longest discussion is that of problem 1, which is devoted to explaining the alleged fact that larger balances are more accurate than smaller ones. The reason for this is the property of the circle mentioned already at 848 a 14 - 19: of two points lying on the same radius, the point farther from the center travels faster as the circle rotates. In problem 1, however, the author attempts to explain why this is so. His discussion raises a number of difficulties that I cannot discuss here. What is important for present purposes is that he analyzes circular motion into a combination of 'natural' (kata phusin) motion along the tangent and motion para phusin towards the center. The basic idea underlying his explanation is simple: because the motion of a point on a longer radius is less deflected (ekkrouesthai) towards the center than the motion of a point on a shorter radius, it travels more quickly,

operation of any of these mechanical devices for those with the requisite knowledge, and that the written literature on mechanics was dedicated to transmitting such knowledge. $\mathrm{Cf}$. the remarks of Aristotle discussed in the next paragraph, as well as ps.-Alex., Quaest., Pr. 32 - 34 Ideler: "For the craftsman (technitês) who has constructed a mechanical device (ergon ti mêchanikon) knows all the causes (aitiai) of its activities, while the lay person (idiotês) is completely ignorant of these causes."

${ }^{43} \mathrm{Cf}$. Lloyd 1979, 51-2, referring to the notion that all phenomena have a natural cause: " 'Marvels' (thaumata) and 'monsters' (terata) then pick out phenomena that are unusual but in principle intelligible, even if not yet understood."

${ }^{44}$ Arist. Metaph. 983 a $12-20$.

${ }^{45} \mathrm{Cf}$. Micheli 1995, 141-3, arguing (I believe incorrectly) that the wonder of mechanical phenomena is not due solely to ignorance of their cause. 
i.e. it covers a greater distance in the same time ( 849 a $6 \mathrm{ff}$.). What is the sense of para phusin in this passage? Nothing speaks for sense 1: there is no break in the natural order of cause and effect here, only the constraint of a body's natural motion in a way that is subject to precise geometrical analysis. The closest match is evidently with sense 2: para phusin referring to forced motion in the Aristotelian sense. Yet in some respects the author's analysis seems remarkably un-Aristotelian. It has often been supposed that because the subject under discussion in problem 1 is the motion of the balance, the author conceives of motion along the tangent as kata phusin because it is directed downward, i.e. in the direction of the natural tendency of a heavy body. But in fact it becomes clear in the sequel that this analysis is a very general one that is meant to apply to all cases of circular movement - including the rotation of a circle that moves in a plane parallel to the ground, e.g. a potter's wheel (cf. ch. 8, 851 b 19 - 21; 852 a 1 ff.). The author's idea seems to be that an object moving in a circle will naturally fly off at a tangent, however the circle may be oriented with respect to the ground. At most, then, we may say that para phusin is used here of motion that is caused by external force or compulsion. The upshot is that mechanical effects that are explicable in terms of circular motion involve a certain amount of external force or compulsion.

In the remaining 34 problems the author largely follows the program stated in the introduction: mechanical phenomena are analyzed in terms of the lever, the balance, or by direct application of the circular motion principle. It is notable that the author does not use the phrase para phusin again after problem 1, not even in connection with the lever. Moreover in a number of cases the mechanical effect in question can be understood as assisting rather than working against a body's natural motion. Problem 8 discusses why circular and round bodies are easiest to move (851 b $15 \mathrm{ff}$.). In the case of a circle standing upright on a horizontal surface (i.e. a wheel), one reason is that the circle is moved in a direction in which it already inclines (repei) by virtue of its weight ( $851 \mathrm{~b} 27$ - 33). In the case of a circle that turns in a plane parallel to the ground (such as a potter's wheel), the author makes a clear reference back to the analysis of circular motion in chapter 1: movement along the tangent is natural (kata phusin), and the mover pushes a circle along the tangent (852 a 7 - 13). In both cases, then, to set a circle in rotation is to cause it to move in a way in which it is already naturally disposed to move; machines that take advantage of the ease with which round and circular bodies can be moved thus assist their natural movement rather than working against it. ${ }^{46}$ Problem 19 asks why an ax placed on a block of wood does not split the wood if a heavy weight is placed on it, but does if one raises it and strikes the wood. The reason is that "a heavy object takes on the movement of weight more when it is moving than when it is at rest" (853 b 19-20). That is, the force generated by the blow augments the natural downward tendency of the weight of the ax. In such cases, the mechanical effect in question is para phusin only in the sense that it goes beyond what unaided nature can achieve (sense 4) and involves some external force or compulsion (sense 2).

\footnotetext{
${ }^{46} \mathrm{Cf}$. problem 11, which asks why heavy weights are more easily carried on rollers than on carts. The reason, in part, is that "a weight resting on rollers moves at two points of them, the ground supporting from below and the weight pressing from above; for the circle is revolving at both these points, and is impelled in the direction it travels" (852 a 34 - 37).
} 
In sum, the author's conception of the art-nature relationship is best understood as the claim that art goes beyond $\mathrm{n}$ ature in bringing about effects that unaided nature cannot (para phusin in sense 4). This is supported by the work's opening, where the apparent opposition between art and nature in fact amounts to a contrast between the complexity of the former and the simplicity and uniformity of the latter. Nothing in the opening suggests that art produces a break or rupture in the order of nature (para phusin in sense 1), or even that it works against the natural tendencies of bodies (para phusin in sense 2). Rather, the author describes art as going beyond what unaided nature can achieve by making creative use of the behavior of nature itself. This calls for the kind of inventive ingenuity associated with the term mêchanê, understood as a 'device' that makes it possible to achieve results that could not otherwise be attained. Insofar as art is able to 'conquer' nature, it is by the creative combination of natural regularities to produce effects that are beneficial for human beings. What distinguishes mechanical effects in particular is their unusual or paradoxical character, as manifest in a reversal of the normal or natural relationship between forces (para phusin in sense 3). The remainder of the introduction and the author's detailed discussion of 35 mechanical problems confirms this analysis. Mechanical phenomena are wondrous because of their unusual or paradoxical character; but this disappears once they have been explained, and it implies no break in the order of nature. Circular motion is the fundamental explanation of all mechanical phenomena; it is analyzed in precise geometrical terms as a combination of motion kata phusin along the tangent and para phusin towards the center. This analysis suggests that the author conceives of mechanical phenomena as involving some external force or compulsion (para phusin in sense 2). But several of the mechanical phenomena the author discusses involve the use of force to augment rather than to counter an object's natural tendencies. The claim that mechanics involves some external force or compulsion is simply a way of indicating that mechanics, as a technê, modifies the natural behavior of the objects with which it deals. And this is best understood as the claim that mechanics goes 'beyond nature' in the sense that I have explained.

As a confirmation of this interpretation, I note that Latin translators and commentators of the early modern period tend to render the phrase para phusin in the Mechanical Problems as praeter naturam. ${ }^{47}$ The basic meaning of the Latin word praeter is 'beyond'; though it can also mean 'against' or 'contrary to', it is much more likely to have the former meaning, especially since the phrase contra naturam was available to express the latter idea (and Latin contra can only mean 'against'). From at least the thirteenth century on, medieval and early modern writers recognized a category of what may be called 'preternatural phenomena' - phenomena which, though they went 'beyond nature' (praeter naturam) in being unusual or exceptional, did not lie outside the order of nature. The early moderns' tendency to render para phusin as praeter naturam in the Mechanical Problems suggests that they placed mechanical phenomena in this category; in doing so, they faithfully rendered the author's idea that mechanics goes beyond nature without breaking the natural order. ${ }^{48}$

\footnotetext{
${ }^{47}$ Noted by Micheli (1995, 26 n. 21); for representative examples see Piccolomini 1565, Monantheuil 1599, del Monte 1588, and cf. section 6 below.

${ }^{48}$ For the category of preternatural phenomena see Daston and Park 1998, 121-2, noting its appearance in Aquinas; the adjective praeternaturalis is found in Albertus Magnus (Metaph. II.xi; cf. OED
} 
This interpretation of the author's view of the art-nature relationship has the further advantage of ascribing to him a view that captures the actual relationship of technology to nature much better than the notion of struggle against a hostile nature. Though machines do bring about effects that go beyond what unaided nature can achieve, it is implausible to suppose that this is because they consistently strive to thwart nature's activity. While some machines may cause bodies to move in ways that are contrary to their natural tendencies, it is by no means the case that all do. And even if a machine does produce such motions, there is no reason to think that it does so by forcing all its components to act against their natural tendencies. It is much more plausible to suppose that in building a machine a craftsman takes advantage of the natural properties of its components, combining them in such a way that they produce an effect that nature cannot. The essence of the machine, and indeed of technê in general, lies in the creative combination of natural regularities. This seems to me an insight that not only captures the view expressed by the author of the Mechanical Problems, but one which is also substantially correct. ${ }^{49}$

\section{Mechanics and the imitation of nature}

Now that we have clarified the conception of the art-nature relationship in the Mechanical Problems, we can return to the question broached at the end of section 2: does mechanics occupy a distinctive position in its relationship to nature vis a vis the other technai in antiquity? As far as the Mechanical Problems is concerned, this question must be answered in the negative. In fact, Aristotle's remark at Phys. 199 a $15-17$ that art either imitates nature or completes what nature leaves unfinished provides an excellent illustration of the art-nature relationship as the author of the Mechanical Problems conceives of it. As we have seen in section 2, the notion of imitation presupposed by Aristotle's remark goes far beyond mere mimicry. Art's imitation of nature must be understood in terms of a close analogy between artificial and natural processes: art imitates nature by acting in an analogous manner. And Aristotle's remark also gives a precise sense to the notion that art goes beyond nature: art brings about results that nature cannot and thus remedies nature's deficiencies, but it does so by acting in the way that nature would act if it could bring about such results. The role of art is to

s.v. 'preternatural'). By the late sixteenth century the term preternatural had entered English, where it referred to something "That is out of the ordinary course of nature; beyond, surpassing, or differing from what is natural; non-natural" (OED s.v. a). Though originally distinct in meaning from supernatural, it was sometimes synonymous with it; cf. OED s.v. b. For the distinction between the preternatural and the supernatural cf. the definition of the former in Webster's Revised Unabridged Dictionary of 1913: "Beyond or different from what is natural, or according to the regular course of things, but not clearly supernatural or miraculous; strange; inexplicable; extraordinary; uncommon; irregular; abnormal; as, a preternatural appearance; a preternatural stillness; a preternatural presentation (in childbirth) or labor."

${ }^{49} \mathrm{Cf}$. the general remarks of Schadewaldt on the way in which technology can be said to surpass nature (1970a, 897): "Die Technik greift die Stoffe und Kräfte der selbstgewachsenen Natur auf, formt sie durch Trennen und Neu-Verbindungen um und gestaltet sie in charakteristischer Weise in diesen neuen Kombinationen auf die Bedürfnisse des Menschen hin. Mit anderen Worten: Die Technik kultiviert die Rohstoffe, die die Natur ihr liefert, und mit diesem Kultivieren, Veredeln auf den Menschen hin mag sie wohl auch die Natur in bestimmter Weise 'übertreffen'." 
build on and extend nature's activities in a way that is beneficial for human beings. Art goes beyond nature and thus may be said to 'conquer' it, but only by imitating nature itself. This is precisely the idea expressed at the opening of the Mechanical Problems: art makes creative use of natural regularities to go beyond what nature itself can achieve. The author seems to identify the use of external compulsion or force as one respect in which mechanics goes beyond nature. But as noted in section 2, for Aristotle the artnature distinction often amounts to no more than a distinction between an external and internal principle of change; the actual process of change is identical, whether the cause is internal or external. Given this, the notion that mechanics involves external force or compulsion by no means stands in the way of a close analogy between mechanical and natural processes. Mechanics brings about effects that unaided nature cannot, but it does so by acting in a way that is analogous to that of nature itself. ${ }^{50}$

\footnotetext{
${ }^{50}$ The importance of Physics 199 a $15-17$ for the interpretation of the Mechanical Problems is noted and emphasized by Schadewaldt (1970b, 916-917); Schneider (1989, 263); and Micheli (1995, 30-1). The ancient commentators held that in remarking that art brings to completion what nature cannot Aristotle had in mind the specific example of medicine, understood as an art that perfects an internal principle of change (cf. Simplicius, In Aristotelis physicorum libros commentaria, Commentaria in Aristotelem Graeca [CAG] 9, 378.6 ff.; Philoponus, In Aristotelis physicorum libros commentaria, CAG 16, 310.16 ff.; 316.21 ff.). On this view the remark would not be applicable to mechanics, insofar as mechanics involves the modification and rearrangement of material bodies rather than the perfection of their internal principle of change. But first, what Aristotle says is that art is able to bring to completion (epitelein) what nature cannot, not that art is able to bring nature itself to a greater state of perfection. Nature is viewed as deficient, and art as making up for these deficiencies; cf. Arist. Pol. 1336 b 40 - 1337 a 3 ("The poets who divide ages by sevens are in the main right: but we should observe the divisions actually made by nature; for the deficiencies (to prosleipon) of nature are what art (technê) and education seek to remedy (anaplêroun).") and Protrepticus, fr. 13 (quoted below). Moreover, I see no reason to suppose that Aristotle is thinking of medicine at Physics 199 a $15 \mathrm{ff}$. There is no mention of medicine in the immediate context; the example Aristotle gives is of the building of a house, which involves the arrangement and fitting together of natural substances rather than a perfection of their internal principle of change. In fact housebuilding or shipbuilding (cf. $199 \mathrm{~b} 28$ - 9) provides an excellent example of art going beyond nature in a way that is suited to human needs. Medicine, by contrast, would be a poor example to illustrate the ability of art to bring nature to a state of greater perfection, for medicine (understood as treatment of the sick) simply restores a patient's nature to its original state of health rather than making it more perfect. Finally we may consider fragment 13 of Aristotle's Protrepticus, which provides a sort of commentary on the thought of Physics 199 a $15 \mathrm{ff}$.: "Natural things come to be for the sake of something and always exist for the sake of something better than artificial things: for nature does not imitate (mimeitai) art, but art imitates nature, and it exists to render aid and make up for (anaplêroun) what nature leaves undone ( $t a$ paraleipomena tês phuseôs). For nature is evidently able to bring to completion (epitelein) some things by itself without any aid, while other things it is barely or not at all able to bring to completion, as is the case with generation: for some seeds will sprout in whatever ground they are sown without any cultivation, while others have need of the art of farming. Similarly, some animals attain their full nature by themselves, while human beings have need of many arts for their survival - both when they are first born and again for their later nourishment." Here art is pictured as helping nature (understood as the internal principle in the seed, or in a human being) to attain a greater state of completion than it could if unaided. But the main point lies in art's ability to modify the behavior of the natural world in beneficial ways - ways that enable human beings to make up for their natural deficiencies. Again, the background is provided by accounts of cultural history in which human beings are pictured as inferior to animals in qualities such as strength and speed, but as making up for this by means of intelligence and technê. The locus classicus for this idea is the story of Prometheus and Epimetheus as told in Plato's Protagoras (320 c ff.): thanks to Epimetheus' forgetfulness, human beings come into the world "naked, unshod, unbedded, and unarmed" (321c); Prometheus gives them the technai to compensate for these disadvantages.
} 
In this connection it is relevant to note that the idea that mechanics imitates nature is associated with two branches of ancient mechanics in particular: the building of automata and of armillary spheres to represent the motions of the heavenly bodies. The notion that these branches of mechanics imitate natural motions appears in both Pappus and Proclus. ${ }^{51}$ The idea of mechanics as imitating nature is also prominent in the following passage from the late Latin writer Cassiodorus (from a letter addressed to Boethius):

All fields of study - the combined efforts of the wise - seek to know the power of nature, insofar as they are able; a machine is the only thing that seeks on the contrary to imitate (imitari) and, if it may be said, in some respects even strives to surpass (superare) it. For this art is distinguished by having made Daedalus fly, by having caused an iron Cupid to hang in the temple of Diana without any fastening; even today it makes mute things sing, lifeless things live, immobile things move. The mechanician is, if it may be said, almost on a par with nature; by throwing open what is hidden, altering what is manifest, sporting with what is wondrous, he simulates so well that what is not doubted to be artificial (compositum) is judged to be the real thing. ${ }^{52}$

\footnotetext{
${ }^{51}$ For the building of automata as imitation cf. Pappus' reference to "those who seem to imitate (mimeisthai) the motions of living things through ropes and cables, as does Hero in the Automata and Balances" (1024.25-27 Hultsch) and Proclus' mention of the manufacture of devices that operate "through ropes and cables, which imitate the motions and impulses of living things" (In Prim. Euc. Elem., p. 41.13-15 Friedlein.) Pappus refers to armillary spheres as an "image" (eikôn) of the heavens; cf. also Cic. Tusc. 1.63 and Cassiodorus, Variae 1.45: Parva de illa (sc. arte mechanica) referimus, cui caelum imitari fas est.

In Pappus the notion of mechanics as imitation is combined with the idea that it brings about effects that are para phusin. Cf. 1022.8-12 Hultsch (from the introduction to Pappus' account of mechanics in general): "[Mechanics] examines bodies at rest and in motion, and their locomotion in general; it not only assigns causes of natural (kata phusin) motion, but also by forcing bodies from their natural places contrary to their natures (para phusin) it devises means of setting them into opposite movements." Here, however, the phrase para phusin is clearly used in its Aristotelian sense of motion that is produced by compulsion and opposed to a body's natural inclination (sense 2 as distinguished above). Notably, Pappus describes mechanics as concerned with both the natural and the forced motion of physical bodies. And elsewhere in Pappus' account the phrase para phusin is used in connection with only one branch of mechanics, the art of those who "raise large weights contrary to nature (para phusin) by means of machines, moving them with a smaller force (dunamis)" (1024.14-16 Hultsch). For Pappus the notion that mechanics acts para phusin no more implies a break in the order of nature than it does for the author of the Mechanical Problems; both forced and natural motions fall under the scope of mechanics, and both can be explained in precise geometrical terms. There is no real tension between the notion that mechanics imitates nature and the notion that it brings about effects that are para phusin in the sense that Pappus describes.

${ }^{52}$ Cassiodorus, Variae 1.45 Mommsen: Universae disciplinae, cunctus prudentium labor naturae potentiam, ut tantum possint, nosse perquirunt: mechanisma solum est quod illam ex contrariis appetit imitari et, si fas est dicere, in quibusdam etiam nititur velle superare. Haec enim fecisse dinoscitur Daedalum volare; haec enim ferreum Cupidinem in Dianae templo sine aliqua illigatione pendere; haec hodie facit muta cantare, insensata vivere, immobilia moveri. Mechanicus, si fas est dicere, paene socius est naturae, occulta reserans, manifesta convertens, miraculis ludens, ita pulchre simulans, ut quod compositum non ambigitur, veritas aestimetur. I am grateful to Bill Newman for the reference and to Malcolm Hyman for discussing the translation with me.
} 
Here the notion of conquering or surpassing nature (superat) appears alongside that of imitation (imitari). The passage suggests that the mechanician can surpass nature by imitating it, in the sense that he creates an imitation that is more lifelike than nature itself. $^{53}$

In Cassiodorus it is clear that what the mechanician creates is but an imitation of nature: the observer who is not in on the trick is fooled, though the craftsman himself is not. But other ancient sources raise at least the theoretical possibility of building a machine that not only mimics or simulates a living thing, but one that actually replicates the very processes going on inside living things. Evidence for this is provided by Gregory of Nyssa's On the Soul and Resurrection, a work that is cast as a dialogue between Gregory himself and his sister Macrina. Plagued by grief at the death of a close friend, Gregory comes to Macrina in search of consolation; the two then engage in a lengthy discussion that raises fundamental questions about the nature of the soul. Throughout Macrina speaks from the perspective of a committed Christian whose views are thoroughly informed by the heritage of Greek philosophy. She gradually brings Gregory from a state in which he is tempted by Epicurean materialism to a full acceptance of the Christian doctrine of resurrection of the flesh. At one point early in their conversation, Gregory asks whether the existence of a certain kind of machine does not make the appeal to an immaterial soul superfluous:

What ... if someone were to say that, just as there is something material common to the perceptible nature of the elements, but great differences between each form of matter according to its distinctive character...there is a faculty (dunamis) compounded from these according to proportion, a faculty that brings about intellectual impressions and movements by virtue of its natural peculiarity and power (dunamis)? Indeed, we often see such things brought about by the makers of machines (mêchanopoioi), at whose hands matter arranged in an artistic fashion (technikôs) imitates nature (mimeitai tên phusin): the matter displays resemblance not only in its shape, but it also moves, and feigns (hupokrinetai) a kind of voice...and we discern no intellectual faculty (noêtê dunamis) bringing about these individual things... ${ }^{54}$

The success of the builders of automata in imitating life prompts Gregory to ask whether the kinds of behavior normally attributed to the intellectual faculty of the soul cannot be explained by virtue of some "motive faculty (kinêtikê dunamis) in the nature of the elements within us." ${ }_{55}$ Macrina responds that the construction of a machine requires technê, which in turn implies the existence of a creative intelligence and a soul:

To know in this way how to take in hand and arrange lifeless matter, so that the art (technê) incorporated into machines practically becomes a soul to the matter, and thus the matter acts out (kathupokrinetai) motion and sound, and

\footnotetext{
${ }^{53}$ The idea of art that seems more real than the real thing has a long tradition, going back to references in early Greek poetry to the mythical craftsman Daedalus and his stunningly faithful depictions of living things. See Morris 1992, $217 \mathrm{ff}$.; I am grateful to Bill Newman for this reference.

${ }^{54}$ De an. et resurr. $33 \mathrm{C}-36$ A Migne.

${ }^{55}$ De an. et resurr. 36 A 10-12 Migne.
} 
shapes, and similar things: this is a proof that there is something in the human being by means of which it is naturally able to conceive of these things through its faculty (dunamis) of contemplation and discovery, and first to construct machines (mêchanêmata) in thought, then bring them into existence through art (technê) and display its thought in matter. ${ }^{56}$

Macrina continues with a remarkable passage that describes the elementary principles of pneumatics that the maker of any such machine needs to know. But, she claims, if the capacity for creating such wondrous effects were present in the nature of the elements themselves, machines would arise spontaneously. ${ }^{57}$ Besides showing that the notion that mechanics imitates nature was sometimes understood as implying a very close analogy between them, Gregory's objection and Macrina's response provide a beautiful illustration of the idea that the essence of a machine lies in the creative arrangement of its components. The operation of a machine is fully natural in the sense that it can be explained by the natural behavior of the substances of which it is made, once they have been placed into a certain arrangement. The contribution of technê lies in the creation of such an arrangement. Even if the processes that go on in the living thing could be replicated in a machine, there is still a place for an immaterial soul: for machines do not make themselves.

Finally on the subject of imitation, a passage from book 10 of Vitruvius suggests that human beings learned to construct machines from the study of nature itself:

Now all machinery (machinatio) has its origin in nature, and is founded on the teaching and instruction of the revolution (uersatio) of the world. Let us but observe and contemplate the natural system formed by the sun, the moon and the five planets; unless these revolved by skillful contrivance (machinata uersarentur), we would not have had the alternation of day and night, nor the ripening of fruits. Thus, when our ancestors had seen that this was so, they took examples from nature, and by imitating them (imitantes) and being led on by divine facts, developed applications that are serviceable in life. Some things, with a view to greater convenience, they worked out by means of machines and their revolutions (uersationibus), others by means of engines; and so, whatever they found useful in practice, they took care to improve by means of study, arts, and doctrines established step by step. ${ }^{58}$

\footnotetext{
${ }^{56}$ De an. et resurr. $36 \mathrm{~B}$ Migne.

${ }^{57}$ De an. et resurr. $36 \mathrm{C}-40$ A Migne.

${ }^{58}$ Vitruv. 10.1.4, pp. 5-6 Callebat/Fleury: Omnis autem est machinatio rerum natura procreata ac praeceptrice et magistra mundi uersatione instituta. Namque animaduertamus primum et aspiciamus continentem solis, lunae, quinque etiam stellarum naturam; quae ni machinata uersarentur, non habuissemus interdum lucem nec fructum maturitates. Cum ergo maiores haec ita esse animaduertissent, e rerum natura sumpserunt exempla et ea imitantes inducti rebus diuinis commodas uitae perfecerunt explicationes. Itaque comparauerunt, ut essent expeditiora, alia machinis et earum uersationibus, nonnulla organis, et ita quae animaduerterunt ad usum utilia esse, studiis, artibus, institutis gradatim augenda doctrinis curauerunt.
} 
The first remarkable feature of this passage is its emphasis on the natural character of mechanics: far from any notion that machines somehow break the order of nature, mechanical motions are produced by nature itself. Second, the passage identifies the imitation of nature as the driving factor in the development of technology. By imitating nature's own movements, human beings learn to build machines that go beyond nature in ways that improve the human condition. The passage in fact provides an excellent illustration of Aristotle's dictum that art imitates nature and completes what nature leaves unfinished. Moreover, as in Aristotle, the imitation in Vitruvius is more than mere mimicry. Like the author of the Mechanical Problems, Vitruvius claims that the operation of machines can be understood in terms of circular motion..$^{59}$ The present passage implies not only that human beings found examples of machines in nature, but also that they discovered the basic principle that explains their operation from the study of nature. By learning the principles underlying the motions found in nature, human beings gain the understanding needed to build machines that go beyond anything that nature produces on its own..$^{60}$

\section{Mechanics and the study of nature}

I now return to the question of how mechanics could yield knowledge of nature. The evidence considered above suggests two ways in which could do so.

First, mechanics like any other technê could provide models for the understanding of natural objects and processes. Aristotle, for example, often draws parallels between mechanics and nature. In the biological works nature is frequently described as a craftsman that displays the inventive ingenuity associated with the terms mêchanê and mêchanasthai. ${ }^{61}$ At De Motu Animalium 701 b 1 ff. Aristotle likens the motion of animals to that of automatic puppets (automata), a type of mechanical device. At De Motu Animalium $698 \mathrm{~b} 21 \mathrm{ff}$. he appeals to the fact that it is impossible to move a boat unless one rests against an external fixed point to show that the motion of animals and of the cosmos as a whole is only possible in relation to an external fixed point or object. While each of these parallels must be examined on its own terms, taken as a group they suggest that Aristotle did not hesitate to draw analogies between mechanics and nature, or between forced and natural motion, and that such analogies played an important role in the study of nature.

Second, mechanics could provide knowledge of nature through the use of mathematics. Important evidence for this idea is provided by the opening of the

\footnotetext{
${ }^{59}$ See Vitruv. 10.1.1, p. 4 Callebat/Fleury: Machina est continens e materia coniunctio maximas ad onerum motus habens uirtutes. Ea mouetur ex arte circulorum rotundationibus, quam Graeci kyklikēn kinēsin appellant.

${ }^{60}$ In this connection it should be noted that Aristotle himself mentions the circular motion principle that is so important in the Mechanical Problems (i.e. that of two circles rotating around the same center, the larger moves more quickly) in connection with celestial motions; see Cael. 289 b 34 ff. Cf. Krafft 1970, 67 f.; Schneider 1989, 261.

${ }^{61} G A 717$ a 30, 745 a 31; PA 652 a 31, 652 b 21, 653 b 34, etc.
} 
Mechanical Problems, immediately after the author describes such problems as those in which "the lesser master the greater":

These are not entirely identical with physical problems nor entirely separate from them, but they have a share in both mathematical and physical speculations: for the 'how' (to hôs) in them is made clear through mathematics, while the 'about what' (to peri ho) is made clear through physics. ${ }^{62}$

This is the author's most explicit attempt to clarify the relationship between mechanics, physics, and mathematics. The contrast he has in mind between the 'how' (to hôs) and the 'about what' (to peri ho) is not immediately clear. But in fact it seems to express a conception of mechanics close to that of Aristotle himself. In several passages Aristotle mentions mechanics as a science like optics, harmonics, and astronomy, each of which uses mathematics to study physical bodies. In Posterior Analytics A 9 Aristotle states that geometrical proofs can be applied to mechanics and optics, just as the proofs of arithmetic can be applied to harmonics (76 a 23 - 25). In Posterior Analytics A 13 mechanics (ta mêchanika) is said to be subordinate to (literally 'under', hupo) stereometry (a kind of geometry), just as optics is to geometry, harmonics to arithmetic, and "study of the phenomena" (ta phainomena) to astronomy (78 b 36 - 39). Aristotle's conception of subordinate sciences raises many problems, but two features of it are clear and relevant in the present context. First, it is mathematics that provides the explanation in the subordinate sciences. For example, a proposition in optics can be demonstrated by means of geometry, and a proposition in harmonics by means of arithmetic $(A . P O .75 \mathrm{~b}$ $14 \mathrm{ff}$.). The subordinate science is concerned with the fact (to hoti) while mathematics supplies the explanation (to dioti). Second, the subordinate sciences deal with the mathematical properties of physical bodies. In Metaphysics M 3, 1078 a 14 ff. Aristotle states that neither harmonics nor optics conceives of (theôrei) its subject matter qua pitch or qua visual ray; rather, they conceive of their subject matter qua numbers or lines, and the same holds true for mechanics (mêchanikê). In this chapter Aristotle is attempting to clarify the relationship of mathematical objects to physical bodies. His point is that since mathematical properties belong to physical bodies, the mathematician in fact studies the properties of such bodies. But he does not study them qua properties of physical bodies; there are many things that can be said about such bodies simply as (qua) lines or planes, and it is such things that the mathematician studies (cf. 1078 a $5 \mathrm{ff}$.). The harmonic theorist or the student of optics incurs no falsity in abstracting away the physical properties of pitch or the visual ray and considering only their mathematical attributes for the purposes of analysis. Physics B 2 adopts a somewhat different perspective on the question of the subject matter of the subordinate sciences. It begins by raising the general questions of how the mathematician differs from the physicist, and whether or not astronomy is a part of physics (193 b $22-30)$. As in Metaphysics M 3 the mathematician is said to study the attributes of physical bodies, though not qua attributes of such bodies (193 b 31 - 35). At 194 a 7-12 Aristotle contrasts geometry with optics, harmonics, and astronomy, which he calls the 'more physical' (phusikôtera) branches of the mathematical sciences. Geometry studies (skopei) a physical line, but not qua physical;

${ }^{62}$ Mech. 847 a $24-28$. 
optics studies a mathematical line, but qua physical, not qua mathematical. Prima facie Aristotle's position here is opposed to that stated in Metaphysics M 3, for here he insists that the 'more physical' branches of mathematics consider their objects qua physical bodies. But there is no real conflict if we take his point to be that the difference between mathematics and the subordinate sciences lies in the need for the latter to consider mathematical attributes as they occur in particular arrangements of physical bodies. The aim of the subordinate sciences is to explain the behavior of particular kinds of physical objects; Aristotle's idea seems to be that they make use of mathematics to construct models that explain this behavior. The geometer is concerned with anything that can be demonstrated about lines and planes simply by virtue of their nature as lines and planes. But the astronomer is concerned only with those mathematical objects that accurately model the heavenly bodies and their motions; similarly the student of optics is concerned only with those arrangements of mathematical lines that correspond to the physical rays that cause optical phenomena. The apparent tension with the Metaphysics passage is really just a matter of a difference of emphasis. In Metaphysics M 3 Aristotle's emphasis is on the mathematical aspect of the subordinate sciences, i.e. on the point that they treat certain physical bodies as mathematical lines and numbers and incur no falsity in doing so. Physics B 2 does not deny this; rather it makes the point that the astronomer or the student of optics does not study just any mathematical lines, but the ones involved in the explanation of certain physical phenomena. Though mechanics is not mentioned in Physics B 2, there is no reason to suppose that Aristotle did not consider it one of the 'more physical' mathematical sciences.

In stating that mathematics supplies knowledge of the 'how' (to hôs), the author of the Mechanical Problems indicates that it provides the explanatory element in such problems, just as Aristotle claims that explanation in the subordinate sciences is provided by mathematics. And in claiming that the 'about what' (to peri ho) is given by physics, the author echoes Aristotle's idea that the subordinate sciences study physical bodies from a particular point of view. Mechanics uses mathematics to explain the motion of physical bodies, but it is distinct from mathematics in that it is concerned only with the movements undergone by physical bodies in certain arrangements and under certain conditions. This picture of the place of mechanics in relation to physics and mathematics is supported by the use of geometry in the Mechanical Problems itself. Consider once again the discussion of problem 1 . The author begins by asking why (dia tina aitian) larger balances are more accurate than smaller ones. The origin or principle (archê) of this is said to be the fact that a point on a larger circle travels faster than one on a smaller circle, when both are moved by the same force $(848$ b $1-9)$; this, in turn, is because a point on the circumference of a circle is moved by two motions (848 b 9 - 10). After explaining and justifying this idea at some length (in part by making use of geometrical representations of bodies in motion) the author states the basic physical idea that underlies his analysis: if two bodies are moving under the influence of the same force, the one that is more deflected (ekkrouesthai) travels more slowly (849 a 6 - 19). A point on a smaller circle is more deflected than one on a greater circle, i.e. it has a greater component of its motion directed towards the center (para phusin) rather than along the tangent (kata phusin). To establish this fact the author appeals to an elaborate geometrical construction in which lines in the geometrical figure correspond to different components 
of the body's motion; he uses this to prove that the that the line corresponding to para phusin motion is larger in the case of the smaller circle (849 a 21 - 849 b 19). Finally the author states that "the reason (aitia) why the point further from the center is moved more quickly by the same force is now clear" ( 849 b $19-22)$, and proceeds to apply this result to the original question of why larger balances are more accurate (849 b $22-850$ a 2 ). Thus, it is the use of geometry to represent mechanical movements that supplies the explanatory element in mechanics, for geometry explains why the point on the larger radius moves more quickly. More generally, the procedure followed throughout the Mechanical Problems may be described as the use of geometrical models to explain physical phenomena. The key step in the author's analysis of all the problems he discusses is the application of a simple model: the lever, the balance, or the circle. It is the application of the model that supplies the explanation. For example, consider the beginning of problem 4:

Why do the rowers in the middle of the ship contribute most to its movement? Is it because the oar acts like a lever (mochlos)? For the thole-pin is the fulcrum (for it is fixed), and the sea is the weight, which the oar drives back; the sailor is the mover of the lever. ${ }^{63}$

Treating the oar as a lever explains why the rowers amidships exert the greatest force; but the explanation of how the lever operates depends ultimately on the geometrical analysis set out in problem 1. Thus the author may be viewed as using geometry to explain the behavior of a certain set of physical phenomena in a way that closely matches Aristotle's description of the subordinate sciences.

I note in conclusion that none of Aristotle's fleeting references to mechanics (the three passages discussed above) suggests that mechanics is concerned with forced rather than natural motion. All of Aristotle's subordinate sciences deal with the mathematical aspects of physical bodies; all occupy a middle ground between physics and various branches of mathematics. Thus, though distinct from physics, mechanics can provide knowledge of physical objects, and in this way can contribute to the knowledge of nature. It is true that there is a contrast to be drawn with the early modern period, when mechanics comes to be regarded as a part of physics itself rather than a closely related discipline. But the difference here results more from Aristotle's notion of mathematical abstraction than from any idea that mechanics is inherently 'contrary to nature'.

\section{Early Modern Reflections}

In the early modern period the Mechanical Problems became the focus of an extensive commentary tradition to which a number of humanists, mathematicians, and engineers made significant contributions. ${ }^{64}$ The work's striking and problematic opening, with its important implications for the understanding of the art-nature relationship, naturally attracted a good deal of attention, and the remarks of a number of commentators

\footnotetext{
${ }^{63}$ Mech. 850 b $10-13$.

${ }^{64} \mathrm{For}$ an overview of this literature and those who contributed to it see Rose and Drake 1971.
} 
provide close parallels to the analysis given above. In this section I present four illustrations of this in chronological order, each drawn from a late sixteenth-century source. $^{65}$

1. Alessandro Piccolomini's highly influential paraphrase of the Mechanical Problems first appeared in Latin in 1547; a second edition appeared in 1565, and the work was translated into Italian in $1582 .{ }^{66}$ Piccolomini reads the opening of the Mechanical Problems as claiming that art operates differently from nature, since it seeks to further human ends. But art also imitates nature, since it acts in just the way that nature would act if it could achieve the effects brought about by art:

For art, although it imitates nature and assists it, nevertheless brings about many things in a way different from it, with a view to our needs. But it must not be considered any less an imitator (imitatrix) of nature for that reason, since it brings about whatever it does in the way that nature itself would, if it did so. For while nature always acts in the same way in whatever it does, if unimpeded, art, because what is useful, necessary, and helpful for us is varied, also proceeds in a varied manner: in whatever path it takes, it also follows nature. If then it should come about that we are not content with the simplicity of nature (which indeed because of its simplicity is in no way diverse) on account of our varied needs, and thus undertake something against it, then it struggles and contends against us and imposes difficulty on our efforts. Hence in order that we might overcome this difficulty (or rather hesitation) we have need of art, by which we bring about our work, either destroying completely or at least demolishing to some degree the efforts of nature. ${ }^{67}$

Even if unimpeded nature always acts in the same way and art acts in different ways in different situations, art must be understood as following nature in all cases. Such opposition as there is between art and nature (it is more a question of 'hesitation' on nature's part than active resistance) results solely from the fact that nature always acts in the same way, while the needs of human beings vary widely.

2. Giuseppi Moletti, Galileo's predecessor as professor of mathematics at Padua, lectured on the Mechanical Problems in 1581; his notes are preserved in manuscript form

\footnotetext{
${ }^{65}$ Cf. Micheli 1995, $144 \mathrm{ff}$.

${ }^{66}$ On Piccolomini and his influence see Rose and Drake 1971, 81-85.

${ }^{67}$ Piccolomini 1565, 8: Ars enim quamuis naturam imitetur, ac illam adiuuet, multa tamen ut usui nobis esse possint, aliter operatur ac illa facit. Neque minus ob id, naturae imitatrix existimari debet, quippe quae eo modo efficit quicquid facit, quo illamet efficeret, si illud faceret. Nam, tametsi natura eundem semper in quo uis opere suo, si non impeditur, seruet modum ars uero, propterea quod nostra utilitas, usus, atque commoditas multiplex est, multiplici etiam \& illa itinere progrediatur: in quo uis tamen itinere, naturam \& ipsa sequitur. Natura igitur, ex sua simplicitate nequaquam multiformis, si quando euenit, ut eius simplicitate, nos propter multiplices nostros usus non contenti, aduersus ipsam quippiam moliamur, tunc illa contra nitens ac contendens, nostris conatibus difficultatem imponit. quam difficultatem, seu potius haesitationem quandam ut superemus, arte quadam indigemus, qua tandem naturae conatus, uel penitus confringentes, uel aliqua saltem ex parte, demolientes, nostrum opus perficiamus.
} 
at the Bibliotheca Ambrosiana in Milan (MS S.100 sup., folios 1-199 passim) ${ }^{68}$ The lectures are organized around particular topics, and several pages are dedicated to the question "whether the art of mechanics is found in the works of nature" (An in operibus naturae ars mechanica reperiatur) (fol. 22). The problem with which Moletti deals is a familiar one by now: how to reconcile the notion that art imitates nature with the ability of art to bring about effects that nature cannot, and with the ability of some arts (especially mechanics) to conquer nature. Moletti's strategy is to argue that mechanics conquers nature by applying principles that it has learned from nature itself. Thus the circular motion principle so important in the Mechanical Problems was discovered by observing the circular motion of the heavenly bodies; the lever was discovered by observing the joints of animals. In general the art of mechanics is found everywhere in nature, meaning that mechanics operates on fully natural principles.

3. Guidobaldo del Monte's 1588 paraphrasis of Archimedes' On the Equilibrium of Planes (In duos Archimedis Aequeponderantium libros paraphrasis) begins with a general discussion of mechanics that draws heavily on the opening of the Mechanical Problems. ${ }^{69}$ Like Moletti, Guidobaldo's concern is to explain how mechanics can conquer nature while also imitating it. Nature appears to be conquered by art, though in fact it contributes greatly to its own defeat; mechanics is "as much an imitator of nature as a mighty opponent" (tam naturae emula, quam oppugnatrix valida). ${ }^{70}$ The branch of mechanics in which art seems most clearly to conquer nature is that which is concerned with weights and equilibrium, and Guidobaldo turns immediately to this most challenging case. Referring to Physics B 8 as well as the opening of the Mechanical Problems, Guidobaldo claims that the operation of art can be conceived of in three ways: art either imitates nature, brings to completion what nature cannot, or produces results that are beyond or contrary to nature (praeter naturam). But in each of these cases, art must be understood as imitating nature. (1) It is evident that there are many arts whose goal is the imitation of nature, such as sculpture. (2) When art brings to completion what nature cannot, as in medicine, it functions as a tool (instrumentum) of nature, and thus brings about a natural effect; in such cases art acts in exactly the same way as nature would, if it brought about such effects (eodem modo operatur, ac si natura rem ipsam absque artis ope perficere posset). (3) Finally, in cases where art conquers nature and brings about a result that is praeter naturam, it does so by producing a certain disposition or arrangement (dispositio) of bodies, the same arrangement that nature would produce if it intended to bring about those effects. Once bodies are placed in this arrangement their motions follow naturally, since it is natural for the arrangement itself to move in a certain way - even though individual bodies may move in ways contrary to their own individual nature. Thus in the case of the lever, it is natural for a large weight to be raised by a smaller one if the center of gravity lies between the fulcrum and the larger weight; the

\footnotetext{
${ }^{68}$ See Rose and Drake 1971, 93; Nobis 1969. My characterization of Moletti's views is based on my own partial transcription of the relevant folio pages as well as the account of Nobis $(1969,331-2)$.

${ }^{69}$ In the following I paraphrase the argument found on pp. 2-5 of del Monte 1588; an online version of this text is available at http://archimedes.mpiwg-berlin.mpg.de.

${ }^{70}$ The same idea is alluded to near the beginning of the preface to Guidobaldo's influential Mechanicorum Liber of 1577, where mechanics is described as operating "against nature, though emulating its laws" (adversus naturam vel eiusdem emulata leges).
} 
larger weight moves upward naturally (naturaliter), even though such motion is contrary to its own individual nature.

4. Finally, a passage in Henri de Monantheuil's 1599 commentary on the Mechanical Problems describes the goal of art as 'turning' (convertere) or 'accommodating' (accommodare) the constant behavior of nature to human needs. ${ }^{71}$ The difficulty of achieving this stimulates human beings to invent the arts. Following closely the passage of Vitruvius discussed above, Monantheuil argues that mechanics was discovered by the observation and imitation of nature (per imitationem rerum a natura procreatarum).$^{72}$ As in Moletti, the notion that mechanics is discovered by the imitation of nature is combined with the idea that mechanical processes occur in nature itself. Monantheuil describes mechanics as an art that goes praeter naturam, 'beyond nature', in a way that contributes to human needs.

As has often been noted, Galileo at the beginning of Le Mecaniche (1593) insists that mechanics does not operate by tricking nature; nature cannot be deceived, and mechanical effects come about in a fully natural way.$^{73}$ Scholars have sometimes pointed to this claim as marking a radical break with previous views of mechanics, and in particular with the Mechanical Problems. ${ }^{74}$ But the evidence presented in this section shows that the notion that mechanics operates 'according to nature' was quite common in the early modern period. Prompted by the striking opening of the Mechanical Problems, early modern authors attempted to reconcile the text's apparent opposition of art and nature with their view that all processes must take place in a natural way. What is more, the discussion in sections 2 - 5 above shows that it would be a grave mistake to suppose that in doing so, these writers were introducing a radically new idea not present in the ancient texts on which they drew. ${ }^{75}$ Rather than a hallmark of the rejection of Aristotle

\footnotetext{
${ }^{71}$ Monantheuil 1599, 8. Rose and Drake describe Monantheuil's work as "the most complete and erudite of the sixteenth-century commentaries on the Mechanica, though not the most original in outlook" (1971, 100). An online version of the text is available at http://archimedes.mpiwg-berlin.mpg.de.

${ }^{72}$ Monantheuil 1599, 9: Homo enim inquit, animaduertens Solis, Lunae, \& reliquorum planetarum continentes motus, \& machinationes naturales, sine quibus non habuisset in terra lucem, \& fructuum maturitates hinc exempla sumpsit, \& ea imitans, inductus rebus diuinis, commodas vitae perfecit explicationes. Itaque comparauit, vt essent expeditiora alia machinis, \& earum versationibus: alia organis, quaeque obseruauit ad vsum vtilia esse studijs, artibus, institutis, doctrinis gradatim augenda curauit: hinc tandem extat ars quaedam generalis quae difficultati faciendorum praeter naturam ad vtiltiatem hominum succurrit.

${ }^{73}$ Galileo 1960, 147: "These deceptions (sc. the deceptions of mechanicians who attempt to achieve impossible effects) appear to me to have their principal cause in the belief which these craftsmen have, and continue to hold, in being able to raise great weights with a small force, as if with their machines they could cheat nature, whose instinct - nay, whose most firm constitution - is that no resistance may be overcome by a force more powerful than it. How false such a belief is, I hope to make most evident with true and rigorous demonstrations that we shall have as we go along." It should be noted that Galileo attributes this view to practitioners, not to those who proposed the kinds of theories about the nature of mechanics with which I am concerned in the present section.

${ }^{74} \mathrm{Cf}$. Krafft 1970, 160-8.

${ }^{75}$ For one example of this cf. Hooykaas 1963, who exaggerates the originality of Monantheuil's position. Krafft (1970 n. 262 a) recognizes the contribution of Moletti, but evidently thinks it exceptional.
} 
that supposedly characterized the crucial phase in the rise of modern science, the notion that mechanics operates according to nature is in fact a deeply Aristotelian idea. ${ }^{76}$

\footnotetext{
${ }^{76}$ I would like to thank the following individuals for their advice and assistance of various kinds during the preparation of this paper: Jenny Attiyeh, Malcolm Hyman, Bill Newman, and Gisela Striker. Much of this paper was written in the fall of 2003 during a sabbatical year at the Max Planck Institute for the History of Science in Berlin; I would like to express special thanks to Jürgen Renn, Director of Department I of the Institute, for his generous invitation and support.
} 


\section{References}

Apelt, O. (1888). Aristotelis quae feruntur De plantis; De mirabilibus auscultationibus; Mechanica; De lineis insecabilibus; Ventorum situs et nomina; De Melisso, Xenophane, Gorgia. Leipzig: Teubner.

Barnes, J., ed. (1984). The complete works of Aristotle: the revised Oxford translation. Princeton, NJ: Princeton University Press.

Bourgey, L. (1975). "Observation and Experiment in Analogical Explanation." Articles on Aristotle. M. Schofield J. Barnes, R. Sorabji. I. London, Duckworth: 175-182.

Callebat, L. and Fleury, P., eds. (1986). Vitruve: De l'architecture, Livre X. Paris: Les Belles Lettres.

Daston, L. and Park, K. (1998). Wonders and the order of nature: 1150 - 1750. New York: Zone Books.

Galilei, G. (1960). On Motion and On Mechanics. Madison: University of Wisconsin Press.

Gille, B. (1980). Les mécaniciens Grecs: la naissance de la technologie. Paris: Éditions du Seuil.

Hooykaas, R. (1963). "Das Verhältnis von Physik und Mechanik in historischer Hinsicht." Beiträge zur Geschichte der Wissenschaft und der Technik 7.

Krafft, F. (1967). "Die Anfänge einer theoretischen Mechanik und die Wandlung ihrer Stellung zur Wissenschaft von der Natur." In W. Baron, ed., Beiträge zur Methodik der Wissenschaftsgeschichte. Beiträge zur Geschichte der Wissenschaft und der Technik 9, 12-33. Wiesbaden: Franz Steiner.

Krafft, F. (1970). Dynamische und statische Betrachtungsweise in der antiken Mechanik. Boethius: Texte und Abhandlungen zur Geschichte der exakten Wissenschaften 10. Wiesbaden: Franz Steiner.

Krafft, F. (1973). "Kunst und Natur. Die Heronische Frage und die Technik in der klassischen Antike." Antike und Abendland 19, 1-19.

Lloyd, G. E. R. (1966). Polarity and analogy: two types of argumentation in early Greek thought. Cambridge: Cambridge University Press.

Lloyd, G. E. R. (1979). Magic, reason, and experience: studies in the origin and development of Greek science. Cambridge: Cambridge University Press.

Lonie, I. M. (1981). The Hippocratic treatises, "On generation," "On the nature of the child," "Diseases $I V^{\prime \prime}$ : a commentary. Ars Medica II. 7. Berlin: De Gruyter.

Micheli, G. (1995). Le origini del concetto di macchina. Biblioteca di Physis 4. Florence: Olschki.

Monantheuil, H. d. (1599). Aristotelis Mechanica Graeca, emendata, Latina facta, et Commentariis illustrata. Paris: Jeremia Perier.

Monte, G. del (1588). In Duos Archimedis Aequeponderantium libros paraphrasis. Pesaro.

Morris, S. (1992). Daidalos and the origins of Greek art. Princeton, NJ: Princeton University Press. 
Newman, W. (1997). "Art, Nature and Experiment among some Aristotelian Alchemists." In E. Sylla and M. McVaugh, eds., Texts and contexts in ancient and medieval science: studies on the occasion of John E. Murdoch's seventieth birthday, 305-317. Brill's Studies in Intellectual History 78. Leiden: Brill.

Newman, W. (2001). "Corpuscular alchemy and the tradition of Aristotle's Meteorology, with special reference to Daniel Sennert." International Studies in the Philosophy of Science 15(2): 145-153.

Nobis, H. M. (1969). “Über zwei Handschriften zur frühneuzeitlichen Mechanik in italienischen Bibliotheken." Sudhoffs Archiv 53: 326-332.

Piccolomini, A. (1565). In Mechanicas Quaestiones Aristotelis, Paraphrasis paulo quidem plenior. Venice, Traianus Curtius.

Rose, P. L. and Drake, S. (1971). "The Pseudo-Aristotelian Questions of Mechanics in Renaissance Culture." Studies in the Renaissance XVIII: 65-104.

Ross, W. D. (1936). Aristotle, Physics. Oxford: Oxford University Press.

Schadewaldt, W. (1970a). "Natur - Technik-Kunst." Hellas und Hesperien. Gesammelte Schriften zur Antike und zur neueren Literatur in 2 Bänden, 892-906. Zurich: Artemis-Verlag.

Schadewaldt, W. (1970b). "Die Begriffe "Natur" und "Technik" bei den Griechen." Hellas und Hesperien. Gesammelte Schriften zur Antike und zur neueren Literatur in 2 Bänden, 907-919. Zurich: Artemis-Verlag.

Schneider, H. (1989). Das Griechische Technikverständnis: Von den Epen Homers bis zu den Anfängen der technologischen Fachliteratur. Impulse der Forschung 54. Darmstadt: Weidmannsche Buchhandlung.

Vernant, J.-P. (1957). "Remarques sur les formes et les limites de la pensée technique chez les Grecs." Revue d'histoire des sciences 10, 205-225. Reprinted in Mythe et pensée chez les Grecs (1971), vol. 2, 44-64. Paris: F. Maspero. 